\title{
Systematic Review of Vitamin D and Hypertensive Disorders of Pregnancy
}

\author{
Karen M. O'Callaghan ${ }^{1,2}$ and Mairead Kiely ${ }^{1,2, * \text { (D) }}$ \\ 1 Cork Centre for Vitamin D and Nutrition Research, School of Food and Nutritional Sciences, \\ University College Cork, Cork T12 Y337, Ireland; karen.ocallaghan@ucc.ie \\ 2 Irish Centre for Fetal and Neonatal Translational Research (INFANT), University College Cork, \\ Cork T12 DFK4, Ireland \\ * Correspondence: m.kiely@ucc.ie; Tel.: +353-214-903-394
}

Received: 21 December 2017; Accepted: 27 February 2018; Published: 1 March 2018

\begin{abstract}
This narrative systematic review evaluates growing evidence of an association between low maternal vitamin $\mathrm{D}$ status and increased risk of hypertensive disorders. The inclusion of interventional, observational, and dietary studies on vitamin D and all hypertensive disorders of pregnancy is a novel aspect of this review, providing a unique contribution to an intensively-researched area that still lacks a definitive conclusion. To date, trial evidence supports a protective effect of combined vitamin D and calcium supplementation against preeclampsia. Conflicting data for an association of vitamin D with gestational hypertensive disorders in observational studies arises from a number of sources, including large heterogeneity between study designs, lack of adherence to standardized perinatal outcome definitions, variable quality of analytical data for 25-hydroxyvitamin $\mathrm{D}(25(\mathrm{OH}) \mathrm{D})$, and inconsistent data reporting of vitamin $\mathrm{D}$ status. While evidence does appear to lean towards an increased risk of gestational hypertensive disorders at $25(\mathrm{OH}) \mathrm{D}$ concentrations $<50 \mathrm{nmol} / \mathrm{L}$, caution should be exercised with dosing in trials, given the lack of data on long-term safety. The possibility that a fairly narrow target range for circulating $25(\mathrm{OH}) \mathrm{D}$ for achievement of clinically-relevant improvements requires further exploration. As hypertension alone, and not preeclampsia specifically, limits intrauterine growth, evaluation of the relationship between vitamin D status and all terms of hypertension in pregnancy is a clinically relevant area for research and should be prioritised in future randomised trials.
\end{abstract}

Keywords: 25-hydroxyvitamin D; gestational hypertension; preeclampsia; vitamin D

\section{Introduction}

Hypertensive disorders of pregnancy are a major cause of maternal and foetal severe acute morbidity, long-term disability, and mortality. On a global basis, an estimated $10 \%$ of pregnant women suffer from hypertensive disorders, representing a serious threat to public health [1]. Hypertension in pregnancy can be classified by the terms chronic hypertension, gestational hypertension, preeclampsia (PE), or chronic hypertension with superimposed PE [2]. Chronic hypertension refers to a systolic blood pressure (SBP) $\geq 140 \mathrm{mmHg}$ and/or a diastolic blood pressure (DBP) $\geq 90 \mathrm{mmHg}$, on at least two occasions, $4 \mathrm{~h}$ apart, which predates pregnancy or occurs before the 20th week of gestation. If this hypertension develops after 20 gestational weeks, it is referred to as gestational hypertension or pregnancy-induced hypertension (PIH). The presence of proteinuria has been a long-standing criterion used to distinguish PE from PIH. However, proteinuria has been questioned as a prerequisite in recent years [3], and new diagnostic criteria allow for the identification of PE based on new onset hypertension in the absence of proteinuria, but in combination with haematological abnormalities, renal and liver impairment, neurological symptoms, and uteroplacental dysregulation [2,3]. Where PE occurs in 
women with longstanding hypertension, this is termed chronic hypertension with superimposed PE [2].

Affecting an estimated 3-5\% of pregnancies worldwide [4], PE is a heterogeneous disorder that is alleviated only after delivery of the placenta [5]. Globally, PE accounts for more than 70,000 maternal and over 500,000 infantile deaths per annum [6], and treatment of PE in nulliparous women results in a yearly economic burden of $€ 31$ million in the developed world alone [7]. The etiology of PE is not fully discerned and its rapid progression and multisystem involvement challenges the understanding of both the pathogenesis of PE and the development of preventative measures [8]. Initiation of $\mathrm{PE}$ is believed to stem from the immune rejection of cytotrophoblasts during placentation, causing impaired remodelling of the spiral arteries of the decidua and myometrium [9]. In recent years, the discovery of vitamin D-specific receptors and metabolites in the placenta and decidua [10] has highlighted a potential role for vitamin $\mathrm{D}$ in perinatal health, outside of its established role in skeletal mineralisation [11].

Maternal vitamin D metabolism is altered during pregnancy, leading to increased circulating levels of both the vitamin D binding protein (VDBP) [12] and the active metabolite, 1,25-dihydroxyvitamin $\mathrm{D}\left(1,25(\mathrm{OH})_{2} \mathrm{D}\right)$ [13]. At term, expectant mothers have almost twice the concentration of $1,25(\mathrm{OH})_{2} \mathrm{D}$ compared to non-pregnant women [13], of which at least $50 \%$ is thought to be contributed by the placenta and/or decidual tissue $[10,14,15]$. The precise function of this increase in $1,25(\mathrm{OH})_{2} \mathrm{D}$ has not been fully established, but current concepts propose that the surge in $1,25(\mathrm{OH})_{2} \mathrm{D}$ is a physiological response induced to permit immune tolerance through vitamin D pathways at the maternal-foetal interface, thereby supporting proper placentation [16].

Widespread vitamin D deficiency has been reported among gravidae worldwide [17], and the potential of vitamin D to prevent pregnancy-related complications is an area of current focus, however, conclusive evidence from randomised trials to support a role for vitamin D in perinatal health is still pending [18]. Women with PE have been shown to experience alterations in calcium and vitamin D metabolism [19]. In comparison to the normal placenta, mRNA expression for the vitamin D-metabolising enzymes CYP2R1, CYP27B1, CYP24A1, and the vitamin D receptor (VDR) have been increased and decreased in placentas of women with PE [20-22], providing direct evidence for disrupted vitamin D metabolic homeostasis in the preeclamptic placenta [22]. The underlying mechanism for this disruption and its association with PE development is not fully understood. It is hypothesised that low-circulating $1,25(\mathrm{OH})_{2} \mathrm{D}$ leads to an imbalance in immune function, resulting in a shift towards a pro-inflammatory environment [16] and disrupted implantation [19]. Increased tumour necrosis factor (TNF)- $\alpha$ stimulates catabolism of $1,25(\mathrm{OH})_{2} \mathrm{D}$, contributing to the lower circulating calcium levels that are observed in PE-diagnosed pregnancies $[23,24]$. To state that malplacentation results principally from the pro-inflammatory environment induced by Th1 cytokine activity would be considered a narrow interpretation, however, and it is likely that vitamin D may contribute to multiple innate and adaptive immune responses in placental and decidual tissue [16]. Despite the advances made in vitro, association studies of vitamin D and PIH can be difficult to interpret at a clinical level, owing to the uncertainty of the pathogenesis of $\mathrm{PE}$, alongside the multiple roles of vitamin $\mathrm{D}$ in immune function [25].

\section{Objectives}

The purpose of this narrative systematic review was to investigate the association of vitamin D and risk of hypertensive disorders in pregnancy. To date, most systematic reviews have focused on one particular study design only (observational or intervention) [26-28], have specified vitamin D status in the inclusion criteria but excluded studies reporting vitamin D intakes [26,27,29], or have focused on PE but not on other forms of pregnancy-associated hypertension $[26,27,29,30]$. This review aimed to critically evaluate the findings from both observational and interventional studies, in which either vitamin D status or dietary intakes are assessed and includes all outcomes which fall under the umbrella term of gestational hypertensive disorders. Owing to the mixed nature of the study design 
(observational or interventional), the marker of exposure (vitamin D intake or status) and the study outcome (blood pressure, PIH or PE), we did not conduct a meta-analysis as part of this review.

\subsection{PICO}

Population: Apparently healthy women having an uncomplicated pregnancy, not diagnosed with $\mathrm{PIH}$ prior to commencement of the study (with the exception of case-control designs) and for whom vitamin D intake or status data is available.

Intervention and comparison: Vitamin D (ergocalciferol or cholecalciferol) versus placebo or dose response. Dietary vitamin D intake and/or 25-hydroxyvitamin D $(25(\mathrm{OH}) \mathrm{D})$ status.

Outcome: Recorded blood pressure, PIH or PE (as defined by investigator) before onset or at time of delivery.

\subsection{Search Methods}

The Medline (Pubmed) and EMBASE electronic databases were searched from inception to 11 November 2016. A structured search strategy was devised using key terms selected from the Medical Subject Headings (MeSH) database and related text words for "vitamin D", "vitamin D deficiency", "pregnancy", "preeclampsia", "hypertension", and "blood pressure". Where applicable, bibliographies of selected papers were hand-searched for additional references and assessed for inclusion.

\subsection{Inclusion Criteria}

The following inclusion criteria were applied: full text articles published in the English language; apparently healthy pregnancies before diagnosis of $\mathrm{PIH}$; recorded blood pressure outcome; and studies where the vitamin $\mathrm{D}$ intake or status of the mother during pregnancy was available. Studies measuring $25(\mathrm{OH}) \mathrm{D}$ specifically, and not $1,25(\mathrm{OH})_{2} \mathrm{D}$, were included owing to the short half-life of $1,25(\mathrm{OH})_{2} \mathrm{D}$, making this metabolite unsuitable for accurately assessing vitamin D status.

\subsection{Exclusion Criteria}

Articles were excluded from the final review if they fell under any of the following categories: postpartum maternal outcomes only; methodological validation papers or papers relating to experimental techniques; genetic studies; animal or in vitro models excluding clinical data; studies reporting biological mechanisms of vitamin D metabolism only; studies that focus solely on populations with gestational diabetes mellitus and studies involving participants diagnosed with any pre-existing metabolic disorder known to interfere with vitamin D metabolism, including chronic kidney disease and liver or gastrointestinal disorders.

\subsection{Data Collection}

Titles and abstracts generated by the search strategy were screened independently by a single reviewer (K.M.O.C.) and relevant articles were identified for further investigation. Studies were included if they reported original data only. Letters, comments, and editorials were excluded, in addition to duplicate articles and narrative review articles. The most recent comprehensive systematic reviews were included, provided a meta-analysis was also reported. The full texts of relevant abstracts were assessed and articles included in the final search were agreed following discussions with a second reviewer (M.K.). To ensure uniformity, for studies reporting 25(OH)D concentrations in $\mathrm{ng} / \mathrm{mL}$, values were converted to $\mathrm{nmol} / \mathrm{L}$ by multiplying by a conversion factor of 2.5, and vitamin D intakes expressed in $\mu \mathrm{g}$ /day were converted to IU/day, for which $1 \mu \mathrm{g}$ is equivalent to $40 \mathrm{IU}$. For observational studies reporting both vitamin $\mathrm{D}$ status and dietary intake, data relating to $25(\mathrm{OH}) \mathrm{D}$ was prioritised in discussion. For intervention trials, the supplemental dose was discussed in preference to achieved 25(OH)D concentrations, to allow for comparison between the administered dose range, intervention duration and incidence of PIH. 
For clarity, in the absence of a universal consensus on deficiency and sufficiency thresholds for serum 25(OH)D concentrations, throughout the text we used the Institute of Medicine-assigned cut-offs of $<30 \mathrm{nmol} / \mathrm{L}$ to define vitamin D deficiency, with low vitamin $\mathrm{D}$ status referring to values $<50 \mathrm{nmol} / \mathrm{L}[11]$, and have specified alternatives as appropriate.

\section{Results}

The initial search identified 190 papers from 1957 to 2016. Once duplicates were removed, 56 texts remained after titles and abstracts were scanned for relevance. Ten papers were identified through hand-searching bibliographies of relevant texts. Results were filtered according to the search criteria, producing a final selection of 49 papers. Three recent systematic reviews and meta-analyses were included, for which we excluded the individual studies incorporated in these reviews, unless they reported an outcome of interest (e.g., vitamin D status or intake/PE or hypertension) that did not feature in the meta-analysis. In this way, we achieved maximum coverage of potentially neglected outcomes. In addition to the three systematic reviews, 34 studies were included in the final review, consisting of three randomised controlled trials (RCT) and 31 observational studies.

A full description of the search strategy and selection process is provided in Figure 1.

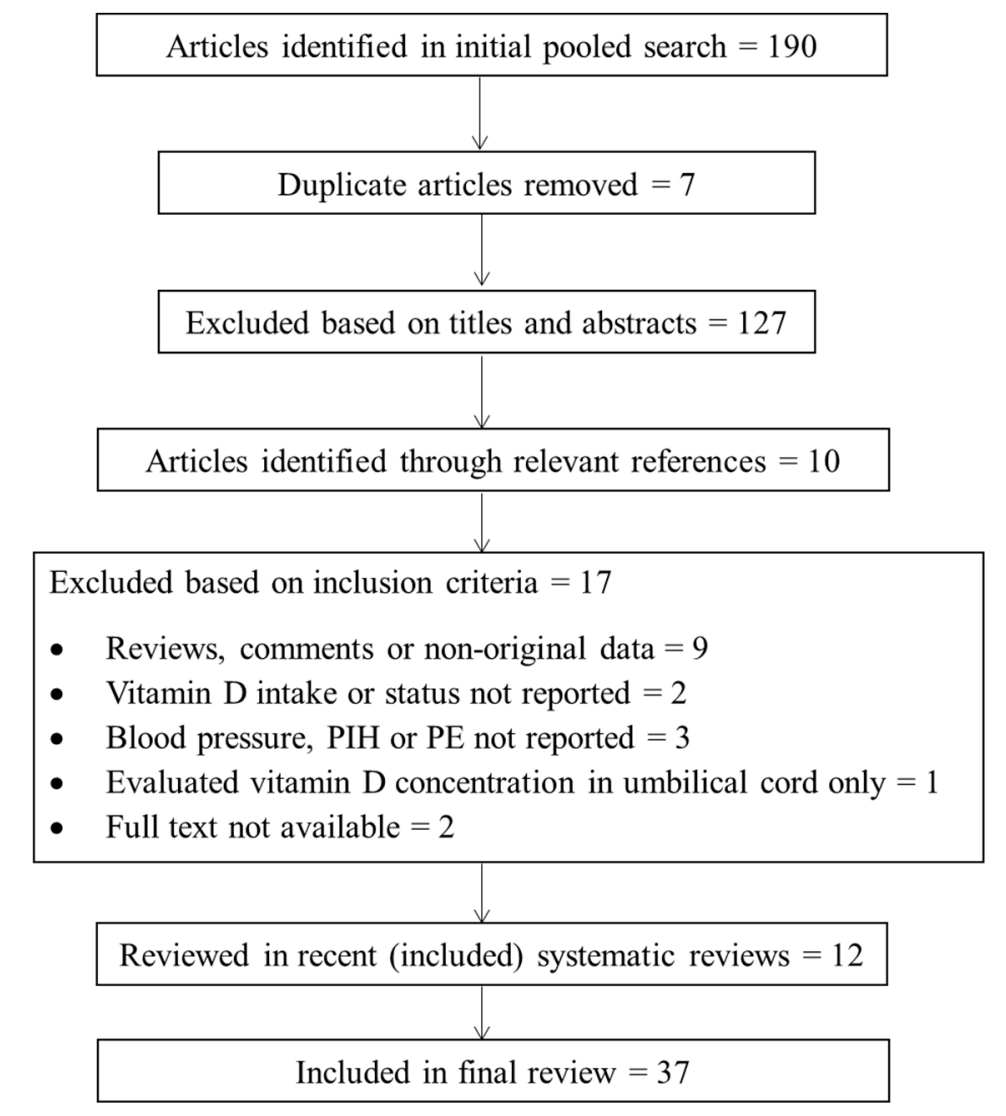

Figure 1. Flowchart of the search strategy and selection process.

\subsection{Intervention Studies}

\subsubsection{Preeclampsia}

In their updated Cochrane systematic review of RCTs, De-Regil et al. [28] reported the effects of vitamin D interventions on several maternal and infant health outcomes, for which two studies focused on PE. Including a small sample of 219 women, the combined analysis from both trials (one providing $400 \mathrm{IU} /$ day, the other providing up to 4 doses of 120,000 IU across gestation) trended towards reduction 
of PE with supplementation $(8.9 \%$ vs. $15.5 \%$; average risk ratio $0.52 ; 95 \%$ confidence interval $(\mathrm{CI})$ : $0.25,1.05)$ [28]. Using the GRADE (Grading of Recommendations, Assessment, Development, and Evaluation) classification [31], this evidence was deemed of low quality, owing to reporting bias and/or selection, detection, performance, and attrition bias of the two studies. An earlier meta-analysis by Hyppönen and colleagues [30] involved four randomised trials of vitamin D supplementation during pregnancy, of which three were placebo-controlled, unblinded studies (dose range 450-1000 IU /day) and a fourth included a group receiving $400 \mathrm{IU} /$ day as a comparator to the two treatment groups (2000 and 4000 IU/day). This review differed from De-Regil [28] in that a placebo/zero intervention group was not a prerequisite, therefore allowing inclusion of vitamin D dose-comparison studies. A similar conclusion was reached of a reduced risk of PE (pooled odds ratio 0.66 ; 95\% CI: 0.52, 0.83, $p=0.001$ ), among supplemented groups. Both meta-analyses highlight insufficient evidence to justify setting a recommendation for supplemental vitamin $\mathrm{D}$ during pregnancy based on the avoidance of PE.

With regard to combined vitamin D and calcium supplementation, the De-Regil et al. [28] meta-analysis of three RCTs $(n=1114$ women) showed a reduced risk of PE ( $5 \%$ vs. $9 \%$; average risk ratio $0.51 ; 95 \%$ CI: $0.32,0.80$ ) in supplemented groups. These studies had lower bias than the two small vitamin D only RCTs and were rated as moderate quality evidence. Collectively, the trial evidence to date supports the view that co-supplementation of vitamin $\mathrm{D}$ with calcium may reduce the risk of PE more than supplemental vitamin D alone, although this comparison is not evenly matched in terms of sample size or study quality.

\subsubsection{Gestational Hypertension}

While most published trials focus on development of PE, few have assessed the impact of supplemental vitamin $\mathrm{D}$ on the risk of hypertension in pregnancy. We identified three recent trials of vitamin $\mathrm{D}$ and gestational blood pressure. Beginning at week 25 of gestation, Asemi [32] noted that a rise in both $\mathrm{SBP}(-0.2 \pm 1.4$ vs. $5.5 \pm 1.6 \mathrm{mmHg}, p=0.01)$ and $\mathrm{DBP}(-0.4 \pm 1.1$ vs. $3.1 \pm 1.1 \mathrm{mmHg}$, $p=0.01$ ) was prevented following 9 weeks of vitamin D supplementation (400 IU/day) compared with placebo. This contrasts with findings of an open-label RCT by Hossain [33] in Pakistani women, where supplemental vitamin D did not influence the risk of gestational hypertension relative to routine antenatal care, at a dose corresponding to the current tolerable upper intake level (4000 IU/day) [11]. When the combination of vitamin D plus calcium supplementation was compared to placebo, SBP was unaffected, but a significant decrease was observed for DBP $(-1.9 \pm 8.3 \mathrm{vs} .3 .1 \pm 5.2 \mathrm{mmHg}$, $p=0.02)$ [34], although in a small sample size $(n=46)$ and with a low supplemental dose (200 IU/day). Careful consideration must be given to the sample populations of these 3 intervention studies. In populations of poor socioeconomic status, with a high prevalence of low vitamin D status and where both calcium and vitamin D intakes are likely to be low, correction of vitamin D and calcium deficiency may reduce the incidence of adverse perinatal outcomes. However, the results may not be generally applicable, but are important for vulnerable populations who would benefit from nutritional intervention.

\subsection{Observational Studies}

\subsubsection{Vitamin D Status and Preeclampsia}

In 2013, Aghajafari et al. [26] published a systematic review and meta-analysis of observational studies, including nine studies that focused on the association of maternal $25(\mathrm{OH}) \mathrm{D}$ status and risk of PE. The combined analysis, using the most adjusted model, found PE to be significantly associated with 25(OH)D concentrations $<50 \mathrm{nmol} / \mathrm{L}$ (pooled odds ratio 1.79; 95\% CI: 1.25, 2.58). Heterogeneity between studies was a limiting factor in the meta-analysis, therefore urging caution in the interpretation of the findings. The authors argued that, given the mechanistic underpinning and biological plausibility of the associations between vitamin $\mathrm{D}$ and metabolic abnormalities including 
hypertension, plus the relative consistency in diverse populations where low 25(OH)D levels often precede the adverse outcome (thus reducing the likelihood of reverse causation), their findings may show a causal relationship if examined in appropriately-designed trials [26].

Following this meta-analysis, prospective observational studies continue to examine the role of vitamin D in PE progression. Results from the large, multi-ethnic, seasonally-balanced GraviD study suggest an increase in $25(\mathrm{OH}) \mathrm{D}$ concentrations of at least $30 \mathrm{nmol} / \mathrm{L}$ from the first to the final trimester is associated with a lower odds of developing PE, irrespective of vitamin D status in early pregnancy. The authors reasoned that $25(\mathrm{OH}) \mathrm{D}$ status at the beginning of gestation may not contribute to placental development but that an increment in concentrations may help protect against the initiation of PE as pregnancy progresses towards the latter stages [35]. A similar theory was reported by Wei [36], whose longitudinal assessment of Canadian gravidae found low vitamin D status in the late, but not early, second trimester was associated with a greater risk of PE. The $30 \mathrm{nmol} / \mathrm{L}$ increase in $25(\mathrm{OH}) \mathrm{D}$ status associated with reduced odds of PE in GraviD corresponds to the observed seasonal variation in vitamin D status in Sweden as well as a lower incidence of PE among women giving birth during summer-autumn compared with winter-early spring [35]. Based on clinical or biochemical assessment, the Evaluating Maternal Markers of Acquired risk of Preeclampsia (EMMA) study identified women $(n=221)$ at high risk of PE in the first half of pregnancy who continued receiving routine antenatal care. Despite the high prevalence (53\%) of low vitamin D status, the subsequent risk of PE was not correlated with maternal 25(OH)D [37]. Without measurement of 25(OH)D status at a time closer to delivery, it is not possible to assess whether an increase in vitamin D status from early to late pregnancy would overcome the acknowledged clinical and/or biochemical abnormalities in early pregnancy, therefore, potentially contributing to the hypothesis described by Bärebring [35] and Wei [36]. The EMMA study is also hampered by the heterogeneity of the study sample, in which $10 \%$ of women were diagnosed with chronic hypertension at enrolment, introducing significant bias [37]. In a smaller $(n=75)$, less affluent cohort, maternal vitamin D status at delivery was identified as an independent predictor of PE diagnosis among women having a singleton pregnancy and attending a tertiary care facility in Pakistan [38]. However, this sample was malnourished, with $45 \%$ having a $25(\mathrm{OH}) \mathrm{D}$ concentration $<25 \mathrm{nmol} / \mathrm{L}$.

Among a large sample of well-characterised, low-risk nulliparous women, with a $17 \%$ prevalence of $25(\mathrm{OH}) \mathrm{D}<30 \mathrm{nmol} / \mathrm{L}$, we recently reported a $36 \%$ reduction in the composite outcome of $\mathrm{PE}$ and small-for-gestational-age birth when $25(\mathrm{OH}) \mathrm{D}$ concentrations exceeded $75 \mathrm{nmol} / \mathrm{L}$ at 15 weeks' gestation [39]. Similarly, the combination of two prospective cohorts in Canada found 25(OH)D concentrations $<30 \mathrm{nmol} / \mathrm{L}$ in early pregnancy led to a greater risk of developing PE when compared to concentrations $>50 \mathrm{nmol} / \mathrm{L}$ [40]. Scholl and colleagues [41] demonstrated a 2.86-fold increased risk of PE in women with elevated parathyroid hormone levels when early pregnancy $25(\mathrm{OH}) \mathrm{D}$ was $<50 \mathrm{nmol} / \mathrm{L}$. This observation led to the development of the "calcium-metabolic stress" concept, whereby a dysregulation of calcium metabolism, resulting from inadequate dietary calcium and/or low 25(OH)D status, causes secondary hyperparathyroidism in pregnancy which, in turn, increases the risk of PE and hypertensive disorders [41].

In terms of analysing interactions between vitamin $\mathrm{D}$ and acknowledged risk factors for PE and pregnancy-induced hypertension, maternal placental growth factor (PIGF) levels were low among women presenting with low vitamin D status in the early and late second trimester [42]. Though both variables were inversely related to PE risk, $25(\mathrm{OH}) \mathrm{D}$ and PIGF were not found to share a mutual causal pathway in the development of PE. Therefore, whether the observed association between $25(\mathrm{OH}) \mathrm{D}$ and PE risk is linked to impaired angiogenesis [42] is questionable. In a prospective study, biochemical and/or biophysical markers of PE development did not differ among first trimester gravidae with or without low vitamin D status [43]. Nonetheless, retrospective analysis has shown an increased risk of late-onset, but not early-onset, $\mathrm{PE}$ among women with low vitamin D status at clinical presentation despite no difference in first trimester 25(OH)D concentrations between PE complicated and non-PE complicated pregnancies [44]. The decrease in $25(\mathrm{OH}) \mathrm{D}$ status in late pregnancy among the PE group 
contrasts to the increase observed for the undiagnosed group, again emphasising the possibility that vitamin D is implicated in PE development in late gestation, independent of differences in the multiple mechanistic pathways of PE pathogenesis in early pregnancy [44].

Apart from longitudinal studies, the relationship between reduced 25(OH)D status and placental biomarkers of PE has been described by Woodham et al. [45] in their nested case-control study of 41 women diagnosed with $\mathrm{PE}$, matched by race/ethnicity to 123 normotensive gravidae at term. In the adjusted regression model, both $25(\mathrm{OH}) \mathrm{D}$ concentration and the soluble fms-like tyrosine kinase-1 (sFLT)/PlGF ratio at the beginning of the second trimester were identified as significant predictors of severe PE, for which women experienced pulmonary oedema, seizures, oliguria, or symptoms of hepatic or cerebral dysfunction, in addition to elevated blood pressure and proteinuria. For each $10 \mathrm{nmol} / \mathrm{L}$ increase in serum $25(\mathrm{OH}) \mathrm{D}$, a $38 \%$ reduction in the odds of developing severe PE was predicted. Similar to that observed in the cohort studies [42-44], no interaction was found between $25(\mathrm{OH}) \mathrm{D}$ status and developmental biomarkers of $\mathrm{PE}$, therefore extending the theory that vitamin $\mathrm{D}$ deficiency and angiogenic factors contribute to PE development through independent mechanistic pathways. Nonetheless, Woodham [45] suggested that combining mid-gestational serum 25(OH)D concentrations with the angiogenic activity factors sFLT and PlGF would yield a better prediction of severe PE than either measure alone. In addition to placental biomarkers, the potential association between vitamin D and markers of oxidative stress [46] and inflammation [47] has also been explored in PE-diagnosed pregnancies at the nested case-control level, both reporting no interaction with $25(\mathrm{OH}) \mathrm{D}$ and subsequent PE risk.

Other nested case-control studies provide weak evidence for an association between early pregnancy vitamin D status and PE development, often concluding that low serum 25(OH)D alone does not contribute to PE risk [48,49], even among large, well-characterised sample populations [50]. Subgroup analysis by season of blood collection has shown support for the correlation between low summer time vitamin D status and PE [48]. However, deficiency during the summer months likely indicates lower mean year-round $25(\mathrm{OH}) \mathrm{D}$ concentrations and it is plausible that the seasonal vitamin D-PE relationship reflects an association of PE with vitamin D among those who consistently present with low 25(OH)D status. Similarly, in the study by Lechtermann et al. [51], serum 25(OH)D levels stratified by season at delivery were increased only among healthy women giving birth during the summer months, but little response to seasonal variation in vitamin D status was observed for those diagnosed with PE. Moreover, the lack of a seasonal elevation in vitamin D status among women diagnosed with PE may inadvertently reflect lower outdoor physical activity levels, whereby risk of developing a hypertensive disorder is highest among women who are least physically active. In terms of vitamin D metabolism, the negative correlation between CYP27B1 and CYP24A1 that occurs in healthy pregnancies was not evident in the preeclamptic placenta in Lechtermann's study [51], leading the authors to believe that the dysregulation of CYP24A1 in PE may contribute to the lack of seasonal variation in $25(\mathrm{OH}) \mathrm{D}$ status among PE-complicated pregnancies. The small number of patients included in the gene expression analysis (13 cases of PE and 14 controls) questions the reliability of these findings and repetition of this analysis in a larger cohort is required. Though once again limited by sample size $(n=48)$, the work by Anderson and colleagues [52] contrasts to that by Lechtermann [51], in which altered placental gene expression of the VDR and CYP27B1 was identified among women diagnosed with PE compared to controls, for which no difference in mean first trimester $25(\mathrm{OH}) \mathrm{D}$ concentrations were observed.

The proposed interplay between angiogenic factors, $25(\mathrm{OH}) \mathrm{D}$ concentrations and PE development has also been explored in case-control studies. Despite an almost 50\% decrease in median $25(\mathrm{OH}) \mathrm{D}$ concentrations among patients with early onset severe PE (EOSPE) compared with gestational age-matched controls, Robinson et al. [53] stressed that $25(\mathrm{OH}) \mathrm{D}$ status could not be identified as a stand-alone diagnostic marker, yet deficiency may contribute to the placental modifications that occur during the early stages of PE development. Regarding vitamin D status alone, a lower median 25(OH)D concentration was found among preeclamptic mother-newborn dyads in Brazil [54], and mean serum 
$25(\mathrm{OH}) \mathrm{D}$ concentrations were significantly reduced among PE-diagnosed Iranian women $[55,56]$ and their neonates [56] compared to controls; however, this is likely confounded by the low socioeconomic status and higher risk of PE in deprived communities.

To our knowledge, only one study examined the association between maternal $25(\mathrm{OH}) \mathrm{D}$ status and risk of eclampsia specifically [57]. Among a case-control analysis involving 33 diagnoses of PE and 79 diagnoses of eclampsia compared to 76 controls, and following adjustment for age, body mass index (BMI), and pregnancy duration, women with a third trimester plasma 25(OH)D concentration $<75 \mathrm{nmol} / \mathrm{L}$ exhibited a three- and five-fold increased risk of developing PE and eclampsia, respectively. However, a cut-off of $75 \mathrm{nmol} / \mathrm{L}$ is a very conservative level to define vitamin D deficiency; only $12 \%$ of women exceeded this threshold. Overall, there was evidence of poor nutritional status, indicated by a low mean BMI $\left(17.7 \pm 2.6 \mathrm{~kg} / \mathrm{m}^{2}\right)$ and a low frequency of supplement use $(23 \%)$ in the sample population. Nonetheless, a comparison of women in the lowest quartile of 25(OH)D concentrations $(<30.1 \mathrm{nmol} / \mathrm{L})$ to those in the highest quartile $(>90.2 \mathrm{nmol} / \mathrm{L})$ found the risk of eclampsia was 17 times greater among women with vitamin D deficiency [57].

The classification of PE by category, as distinguished by mild (SBP $\geq 140 \mathrm{mmHg}$ and/or $\mathrm{DBP} \geq 90 \mathrm{mmHg}$ with proteinuria) or severe (SBP $\geq 160 \mathrm{mmHg}$ and/or DBP $\geq 110 \mathrm{mmHg}$ with elevated proteinuria, plus convulsions or end-organ damage and dysfunction) and its association with vitamin D status, as described by Woodham [45] and Ullah [57], was later explored in two additional case-control designs [58,59]. The analysis by Singla [59], of 74 preeclamptic nulliparous women and 100 controls in India, found maternal 25(OH)D concentrations were negatively associated with blood pressure and risk of PE; however, the severity of PE was not related to vitamin D status. The high prevalence $(>80 \%)$ of low vitamin D status in this study indicates overall nutritional inadequacy, which was poorly characterised, with no data on maternal anthropometry or prenatal supplement use. It is plausible that the gravidae examined by both Ullah [57] and Singla [59] are at an increased risk of adverse perinatal outcomes irrespective of vitamin D status and, therefore, we caution the extrapolation of these findings to the wider obstetric population. Lastly, Bodnar [58] explored the relationship of vitamin D status and PE risk using data from the multi-ethnic Collaborative Perinatal Project, 1959-1966. Here, low vitamin D status was shown to be a risk factor for severe PE only, but not for milder forms of the disease. PE was most often diagnosed among younger, less educated, black women of poor socioeconomic status. Hence, it is argued that the predictors of PE may correspond to the same predictors of low $25(\mathrm{OH}) \mathrm{D}$ status, leading to a biased sample population. Furthermore, the reliability of these results are questionable, as serum $25(\mathrm{OH}) \mathrm{D}$ was measured over 40 years after completion of the study [58].

\subsubsection{Vitamin D Intake and Preeclampsia}

We found only one large prospective cohort that described vitamin D intake in relation to PE. Analysis of vitamin D intakes from over 23,000 nulliparous women participating in the Norwegian Mother and Child Cohort Study [60] found a lower total vitamin D intake was associated with an increased risk of developing PE. Compared to non-supplement users, women taking a vitamin D supplement (400-600 IU/day) had a $27 \%$ reduced risk of PE, potentially supporting the theory of a role for vitamin D supplementation in PE prevention, as was discussed earlier $[28,30]$.

\subsubsection{Gestational Hypertension}

Focusing on gestational hypertension alone, higher plasma $25(\mathrm{OH}) \mathrm{D}$ concentrations were associated with a greater risk of hypertension among 1591 women (16.4-36.9 weeks' gestation) participating in Project Viva [61], corresponding to an odds ratio of 1.32 for each $25 \mathrm{nmol} / \mathrm{L}$ increment in $25(\mathrm{OH}) \mathrm{D}$ concentration. Though contrary to the current hypothesis, such findings support the previously-reported association of higher vitamin D intakes with increased risk of gestational hypertension from this cohort [62]. Nonetheless, a $25 \mathrm{nmol} / \mathrm{L}$ increment is substantial in view of the reported distribution of $25(\mathrm{OH}) \mathrm{D}$ in the Project Viva cohort and among pregnant women 
elsewhere [17,39]. In a much smaller sample $(n=75)$, the prospective cohort of mother-infant dyads by Hossain and colleagues [38], that acknowledged vitamin D status as an independent predictor of PE, also identified maternal $25(\mathrm{OH}) \mathrm{D}$ concentration at delivery as an inverse independent predictor of mean arterial pressure, for which, again, the findings are confined to a specific, vulnerable population. Similar caution should be applied to the large $(n=1000)$ cross-sectional study by Al-Shaikh [63], in which there was also a high prevalence of low vitamin D status $(86 \%)$, and where hypertensive disorders were not seen among women presenting with a $25(\mathrm{OH}) \mathrm{D}$ concentration $\geq 75 \mathrm{nmol} / \mathrm{L}$ at delivery. Furthermore, the frequency of PIH did not differ significantly between those with or without low vitamin D status and the fact that over half $(57 \%)$ the study population were classified as obese upon admission to antenatal care, coupled with an extremely low incidence of $\mathrm{PE}(<1 \%)$, raises concerns as to whether additional cases of PE may have been misdiagnosed or undetected. Irrespective of sample size ( $n$ ranged from 48 to 263) and diversity of the populations studied, case-control studies stratified by maternal vitamin D status [52], total vitamin D intake [52,64,65], or supplement use [55,64], do not report effects on blood pressure or PIH development.

A summary of observational studies that assessed the risk of gestational hypertensive disorders with serum 25(OH)D status or maternal vitamin D intake is provided in Tables 1 and 2, respectively. For ease of understanding, an overview of recent systematic reviews that have explored this topic is provided in Table 3. 
Table 1. Observational studies of serum $25(\mathrm{OH}) \mathrm{D}$ and risk of hypertensive disorders in pregnancy.

\begin{tabular}{|c|c|c|c|c|c|c|}
\hline Author & Year & Design & $n$ & Gestational Age & Outcome & $\begin{array}{r}\text { Significant } \\
\text { Association }\end{array}$ \\
\hline Abedi [55] & 2014 & Case-control & 118 & Delivery & Risk of PE was higher at $25(\mathrm{OH}) \mathrm{D}$ concentrations $<25 \mathrm{nmol} / \mathrm{L}$ (OR $24.04,95 \%$ CI: $2.1,274.8$ ) & Yes \\
\hline Achkar [40] & 2015 & Nested case-control & 2144 & $<20$ weeks & $\begin{array}{l}\text { Risk of PE was higher at } 25(\mathrm{OH}) \mathrm{D} \text { concentrations }<30 \mathrm{nmol} / \mathrm{L} \text { compared to }>50 \mathrm{nmol} / \mathrm{L} \\
(\text { OR } 2.23,95 \% \text { CI: } 1.29,3.83)\end{array}$ & Yes \\
\hline Al-Shaikh [63] & 2016 & Cross-sectional & 1000 & Delivery & $\begin{array}{l}\text { PIH was not seen at } 25(\mathrm{OH}) \mathrm{D} \text { concentrations } \geq 75 \mathrm{nmol} / \mathrm{L} \text { but frequency of PIH was } \\
\text { not significant }\end{array}$ & No \\
\hline $\begin{array}{l}\text { Álvarez-Fernández } \\
{[44]}\end{array}$ & 2015 & Retrospective cohort & 257 & $\begin{array}{l}9-12 \& 20-41 \\
\quad \text { weeks }\end{array}$ & $\begin{array}{l}\text { Risk of late onset PE was higher at } 25(\mathrm{OH}) \mathrm{D} \text { concentrations }<50 \mathrm{nmol} / \mathrm{L} \\
\text { (OR 4.6, } 95 \% \text { CI: } 1.4,15)\end{array}$ & Yes \\
\hline Anderson [52] & 2015 & Case-control & 48 & First trimester & $\begin{array}{l}25(\mathrm{OH}) \mathrm{D} \text { concentrations did not differ between preeclamptic/hypertensive and } \\
\text { normotensive women }\end{array}$ & No \\
\hline Bärebring [35] & 2016 & Prospective cohort & 2000 & $\begin{array}{l}\text { First \& third } \\
\text { trimester }\end{array}$ & $\begin{array}{l}\text { An increase in } 25(\mathrm{OH}) \mathrm{D} \text { of } \geq 30 \mathrm{nmol} / \mathrm{L} \text { was associated with lower odds of PE } \\
\text { (OR } 0.22,95 \% \text { CI: } 0.084,0.581) \text { but not PIH alone }\end{array}$ & Yes \\
\hline Bodnar [58] & 2014 & Case-cohort & 3703 & $\leq 26$ weeks & $\begin{array}{l}\text { Risk of severe PE was lower at } 25(\mathrm{OH}) \mathrm{D} \text { concentrations }>50 \mathrm{nmol} / \mathrm{L} \\
(\mathrm{RR} 0.65,95 \% \text { CI: } 0.43,0.98)\end{array}$ & Yes \\
\hline Bomba-Opon [43] & 2014 & Prospective cohort & 289 & First trimester & 25(OH)D concentrations were not related to early biomarkers of PE & No \\
\hline Burris [61] & 2014 & Prospective cohort & 1591 & 16.4-36.9 weeks & $\begin{array}{l}\text { Higher } 25(\mathrm{OH}) \mathrm{D} \text { concentrations were associated with a greater risk of hypertension } \\
\text { (OR } 1.32 \text { for per } 25 \mathrm{nmol} / \mathrm{L} \text { increment, } 95 \% \mathrm{CI}: 1.01,1.72 \text { ) }\end{array}$ & Yes \\
\hline Gidlöf [49] & 2015 & Nested case-control & 159 & 12 weeks & 25(OH)D concentrations $<50 \mathrm{nmol} / \mathrm{L}$ was not associated with PE & No \\
\hline Hossain [38] & 2011 & Prospective cohort & 75 & Delivery & $\begin{array}{l}\text { Women with } 25(\mathrm{OH}) \mathrm{D} \text { concentrations in the lowest vs. highest tertile were more likely to } \\
\text { develop hypertension (OR 3.38, 95\% CI: 0.40, 28.37) and/or PE (OR 2.28, 95\% CI: 0.35, } \\
23.28) ; \leq 50 \text { nmol/L was identified as the risk threshold }\end{array}$ & Yes \\
\hline Kiely [39] & 2016 & Prospective cohort & 1768 & 15 weeks & $\begin{array}{l}\text { Risk of PE and small for gestational age combined was lower at } 25(\mathrm{OH}) \mathrm{D} \text { concentrations } \\
\geq 75 \mathrm{nmol} / \mathrm{L}(\mathrm{OR} 0.64,95 \% \text { CI: } 0.43,0.96)\end{array}$ & Yes \\
\hline Lechtermann [51] & 2014 & Nested case-control & 63 & Delivery & $\begin{array}{l}\text { Mean } \pm \text { SD summertime } 25(\mathrm{OH}) \mathrm{D} \text { status was lower in women with than without PE } \\
(45 \pm 43 \text { vs. } 123 \pm 73 \mathrm{nmol} / \mathrm{L})\end{array}$ & Yes \\
\hline Mohaghegh [56] & 2015 & Case-control & 91 & Delivery & $\begin{array}{l}\text { Mean } \pm \text { SD } 25(\mathrm{OH}) \mathrm{D} \text { status was lower in women with than without PE } \\
(38 \pm 34 \text { vs. } 58 \pm 38 \mathrm{nmol} / \mathrm{L})\end{array}$ & Yes \\
\hline Pena [54] & 2015 & Cross-sectional & 179 & Delivery & $\begin{array}{l}\text { Preeclamptic mothers had a higher rate of } 25(\mathrm{OH}) \mathrm{D}<50 \mathrm{nmol} / \mathrm{L} \text { than those without } \mathrm{PE} \\
(50 \% \text { vs. } 23 \%)\end{array}$ & Yes \\
\hline Ringrose [64] & 2011 & Case-control & 187 & Delivery & $\begin{array}{l}\text { Hypertensive women had lower mean } \pm \text { SD } 25(\mathrm{OH}) \mathrm{D} \text { concentrations compared with } \\
\text { controls }(62 \pm 26 \mathrm{vs} .70 \pm 29 \mathrm{nmol} / \mathrm{L}) \text { in the univariate analysis but not when controlled } \\
\text { for BMI }\end{array}$ & No \\
\hline Robinson [53] & 2013 & Case-control & 80 & $\begin{array}{c}\text { Diagnosis } \\
\text { (28+ weeks) }\end{array}$ & $\begin{array}{l}\text { Median } 25(\mathrm{OH}) \mathrm{D} \text { concentrations were lower in women with EOSPE than in controls } \\
(42 \text { vs. } 83 \mathrm{nmol} / \mathrm{L})\end{array}$ & Yes \\
\hline
\end{tabular}


Table 1. Cont.

\begin{tabular}{|c|c|c|c|c|c|c|}
\hline Author & Year & Design & $n$ & Gestational Age & Outcome & $\begin{array}{r}\text { Significant } \\
\text { Association }\end{array}$ \\
\hline Schneuer [50] & 2014 & Nested case-control & 5109 & 10-14 weeks & $25(\mathrm{OH}) \mathrm{D}$ status was not a predictor of $\mathrm{PE}$ & No \\
\hline Scholl [41] & 2013 & Prospective cohort & 1141 & $<20$ weeks & $\begin{array}{l}\text { Women with secondary hyperparathyroidism had a }>2 \text {-fold increased risk of PE when } \\
25(\mathrm{OH}) \mathrm{D} \text { concentrations were }<50 \mathrm{nmol} / \mathrm{L}(95 \% \mathrm{CI}: 1.23-, 6.41 \text {-fold })\end{array}$ & Yes \\
\hline Shand [37] & 2010 & Prospective cohort & 221 & $10-20$ weeks & $25(\mathrm{OH}) \mathrm{D}$ status was not related to $\mathrm{PE}$ & No \\
\hline Singla [59] & 2015 & Case-control & 174 & $\begin{array}{c}\text { NS (mean } \\
35-36 \text { weeks) }\end{array}$ & $\begin{array}{l}\text { Mean } \pm \text { SD } 25(\mathrm{OH}) \mathrm{D} \text { status was lower in women with than without PE } \\
(24 \pm 12 \text { vs. } 37 \pm 17 \mathrm{nmol} / \mathrm{L})\end{array}$ & Yes \\
\hline Wei [36] & 2012 & Prospective cohort & 697 & $\begin{array}{l}12-18 \& 24-26 \\
\text { weeks }\end{array}$ & $\begin{array}{l}\text { 25(OH)D concentrations }<50 \mathrm{nmol} / \mathrm{L} \text { at } 24-26 \text { weeks were associated with increased risk of } \\
\mathrm{PE}(\mathrm{OR} 3.24,95 \% \mathrm{CI}: 1.37,7.69)\end{array}$ & Yes \\
\hline Wei [42] & 2013 & Prospective cohort & 697 & $\begin{array}{l}12-18 \& 24-26 \\
\text { weeks }\end{array}$ & PIGF levels were lower in women with $25(\mathrm{OH}) \mathrm{D}$ concentrations $<50 \mathrm{nmol} / \mathrm{L}$ & Yes \\
\hline Wetta [58] & 2014 & Nested case-control & 300 & 15-21 weeks & $25(\mathrm{OH}) \mathrm{D}$ status in early pregnancy was not related to $\mathrm{PE}$ at $<37$ weeks' gestation & No \\
\hline Woodham [45] & 2011 & Nested case-control & 164 & $15-20$ weeks & $\begin{array}{l}\text { For each } 10 \mathrm{nmol} / \mathrm{L} \text { increase in } 25(\mathrm{OH}) \mathrm{D} \text {, risk of severe PE decreased by } 38 \% \\
(95 \% \text { CI: } 0.51,0.76)\end{array}$ & Yes \\
\hline $\mathrm{Xu}[47]$ & 2014 & Nested case-control & 200 & $\geq 24$ weeks & $\begin{array}{l}\text { Risk of PE quadrupled when } 25(\mathrm{OH}) \mathrm{D} \text { concentrations were }<37.5 \mathrm{nmol} / \mathrm{L} \\
\text { (OR } 4.2,95 \% \text { CI: } 1.4,12.8)\end{array}$ & Yes \\
\hline Ullah [57] & 2013 & Case-control & 188 & >20 weeks & $\begin{array}{l}\text { Risk of eclampsia and PE was higher at 25(OH)D concentrations }<75 \mathrm{nmol} / \mathrm{L} \\
\text { (OR 5.14, } 95 \% \text { CI: } 1.98,13.37 \text { and OR 3.9, 95\% CI: } 1.18,12.87 \text {, respectively) }\end{array}$ & Yes \\
\hline Zabul [46] & 2015 & Nested case-control & 74 & Late gestation & $\begin{array}{l}25(\mathrm{OH}) \mathrm{D} \text { status did not significantly differ between preeclamptic and } \\
\text { non-preeclamptic women }\end{array}$ & No \\
\hline
\end{tabular}

BMI, body mass index; CI, confidence interval; EOSPE, early onset severe preeclampsia; NS, not specified; OR, odds ratio; PE, preeclampsia; PIH, pregnancy-induced hypertension; PIGF, placental growth factor; $\mathrm{RR}$, risk ratio.

Table 2. Observational studies of dietary vitamin D intake and risk of hypertensive disorders in pregnancy.

\begin{tabular}{ccccclc}
\hline Author & Year & Design & $n$ & Gestational Age & \multicolumn{1}{c}{ Outcome } \\
\hline Abedi [55] & 2014 & Case-control & 118 & Delivery & Vitamin D supplement use did not differ between preeclamptic and non-preeclamptic women \\
\hline Anderson [52] & 2015 & Case-control & 48 & First trimester & Dietary vitamin D intake did not differ between hypertensive and normotensive women \\
\hline Haugen [60] & 2009 & $\begin{array}{c}\text { Prospective } \\
\text { cohort }\end{array}$ & 23,423 & 15,22 \& 30 weeks & $\begin{array}{l}\text { Women taking a vitamin D supplement (400-600 IU/day) had a reduced risk of PE compared to } \\
\text { non-users (OR 0.73, 95\% CI: 0.58, 0.92) }\end{array}$ \\
\hline Kazemian [65] & 2013 & $\begin{array}{c}\text { Case-control } \\
\text { Oken [62] }\end{array}$ & 263 & $21-35$ weeks & Vitamin D intake was not associated with risk of gestational hypertension \\
\hline Ringrose [64] & 2011 & $\begin{array}{c}\text { Prospective } \\
\text { cohort }\end{array}$ & 1718 & First trimester & $\begin{array}{l}\text { Women with higher vitamin D intakes had an increased risk of gestational hypertension } \\
\text { (OR 1.11 per 100 IU, 95\% CI: 1.01, 1.21) }\end{array}$ \\
\hline
\end{tabular}

OR, odds ratio; $\mathrm{CI}$, confidence interval; $\mathrm{PE}$, preeclampsia. 
Table 3. Summary of recent systematic reviews examining the relationship of maternal vitamin D status and/or intake and risk of preeclampsia

\begin{tabular}{|c|c|c|c|c|c|c|c|}
\hline Author & Year & Design of Studies & $\begin{array}{l}\text { Number of } \\
\text { Studies }\end{array}$ & $\begin{array}{l}\text { Sample } \\
\text { Size }\end{array}$ & $\begin{array}{l}\text { Meta-Analysis } \\
\text { (Yes/No) }\end{array}$ & Outcome & $\begin{array}{l}\text { Association } \\
\text { (Yes/No) }\end{array}$ \\
\hline De-Regil [28] & 2016 & $\begin{array}{l}\text { Randomised } \\
\text { controlled trials }\end{array}$ & 2 & 219 & Yes & $\begin{array}{l}\text { Relative to placebo, a 'trend' in the risk reduction of PE was seen among gravidae } \\
\text { consuming supplemental vitamin } \mathrm{D}^{1} \text { ( } 8.9 \% \text { vs. } 15.5 \% \text {; average risk ratio } 0.52 ; 95 \% \\
\text { CI: } 0.25,1.05)\end{array}$ & Yes \\
\hline De-Regil [28] & 2016 & $\begin{array}{l}\text { Randomised } \\
\text { controlled trials }\end{array}$ & 3 & 1114 & Yes & $\begin{array}{l}\text { Combined supplementation of vitamin } \mathrm{D}^{1} \text { plus calcium resulted in a reduced risk } \\
\text { of PE ( } 5 \% \text { vs. } 9 \% \text {; average risk ratio } 0.51 ; 95 \% \text { CI: } 0.32,0.80)\end{array}$ & Yes \\
\hline Arain [66] & 2015 & $\begin{array}{l}\text { Intervention \& } \\
\text { observational }\end{array}$ & 7 & 26,924 & No & $\begin{array}{l}\text { Risk of PE may be increased at lower levels of } 25(\mathrm{OH}) \mathrm{D}(\mathrm{range}<37.5-75 \mathrm{nmol} / \mathrm{L}) \text {, } \\
\text { but the relationship between vitamin } \mathrm{D} \text { and PE is conflicted by large heterogeneity } \\
\text { between studies }\end{array}$ & Yes \\
\hline Harvey [67] & 2014 & $\begin{array}{l}\text { Intervention \& } \\
\text { observational }\end{array}$ & 12 & 642 & Yes & $\begin{array}{l}\text { Meta-analysis of } 4 \text { observational studies found the risk of PE did not increase with } \\
\text { decreased vitamin D status }{ }^{1} \text { (pooled OR } 0.75,95 \% \text { CI: } 0.48,1.19 \text { ) }\end{array}$ & No \\
\hline Aghajafari [26] & 2013 & Observational & 9 & 3191 & Yes & $\begin{array}{l}\text { PE was significantly associated with } 25(\mathrm{OH}) \mathrm{D} \text { concentrations }<50 \mathrm{nmol} / \mathrm{L} \\
\text { (pooled OR } 1.79,95 \% \text { CI: } 1.25,2.58 \text { ) }\end{array}$ & Yes \\
\hline Hyppönen [30] & 2013 & Randomised trials & 4 & 5982 & Yes & $\begin{array}{l}\text { Women receiving supplemental vitamin } \mathrm{D}^{1} \text { had a reduced risk of PE compared to } \\
\text { controls (pooled OR } 0.66,95 \% \text { CI: } 0.52,0.83 \text { ) }\end{array}$ & Yes \\
\hline Hyppönen [30] & 2013 & $\begin{array}{l}\text { Prospective } \\
\text { observational }\end{array}$ & 6 & 6864 & Yes & $\begin{array}{l}\text { Mothers with higher serum } 25(\mathrm{OH}) \mathrm{D} \text { status }{ }^{1} \text { had a reduced risk of PE } \\
\text { (pooled OR } 0.52,95 \% \text { CI: } 0.30,0.89)\end{array}$ & Yes \\
\hline Hyppönen [30] & 2013 & $\begin{array}{l}\text { Prospective } \\
\text { observational }\end{array}$ & 2 & 77,165 & Yes & $\begin{array}{l}\text { Mothers receiving supplemental vitamin } \mathrm{D}^{1} \text { in early pregnancy had lower odds of } \\
\text { developing PE (pooled OR } 0.81,95 \% \text { CI: } 0.75,0.87 \text { ) }\end{array}$ & Yes \\
\hline Tabesh [27] & 2013 & Observational & 15 & 3007 & Yes & $\begin{array}{l}\text { Eight studies ( } 2485 \text { women) were included in the meta-analysis, for which PE was } \\
\text { significantly correlated with } 25(\mathrm{OH}) \mathrm{D} \text { concentrations }<50 \mathrm{nmol} / \mathrm{L} \text { but not } \\
<38 \mathrm{nmol} / \mathrm{L}\end{array}$ & Yes \\
\hline Wei [29] & 2013 & Observational & 8 & 2273 & Yes & $\begin{array}{l}\text { Risk of PE was increased at } 25(\mathrm{OH}) \mathrm{D} \text { concentrations }<50 \mathrm{nmol} / \mathrm{L} \\
(\mathrm{OR} 2.09,95 \% \text { CI: } 1.50,2.90)\end{array}$ & Yes \\
\hline Christesen [68] & 2012 & Observational & 9 & 24,704 & No & $\begin{array}{l}\text { Risk of PE was inversely associated with a vitamin D intake of } \geq 400-600 \mathrm{IU} / \text { day } \\
\text { and/or status } \geq 37.5-80 \mathrm{nmol} / \mathrm{L} \text { in studies where the number PE cases exceeded } 40 \\
\text { but no association was found in studies with }<40 \text { cases of PE }\end{array}$ & Yes \\
\hline $\begin{array}{l}\text { Thorne-Lyman } \\
\text { \& Fawzi [69] }\end{array}$ & 2012 & $\begin{array}{l}\text { Intervention \& } \\
\text { observational }\end{array}$ & 7 & NS & Yes & $\begin{array}{l}\text { Pooled analysis of } 2 \text { studies, }(>25,000 \text { women), found no difference PE risk when } \\
\text { stratified by highest and lowest categories of total vitamin D intake }{ }^{1} \\
\text { (OR } 0.95,95 \% \text { CI: } 0.86,1.06)\end{array}$ & No \\
\hline Nassar [70] & 2011 & $\begin{array}{l}\text { Nested } \\
\text { case-control }\end{array}$ & 2 & 435 & No & $\begin{array}{l}\text { Sufficient evidence was not available to firmly established an association between } \\
\text { first trimester } 25(\mathrm{OH}) \mathrm{D} \text { status and PE risk }\end{array}$ & No \\
\hline
\end{tabular}

${ }^{1}$ Vitamin D dose range or status as defined in each included study. 25(OH)D, 25-hydroxyvitamin D; CI, confidence interval; NS, not specified; PE, preeclampsia; OR, odds ratio. 


\section{Discussion}

At present, there is insufficient evidence to justify setting dietary vitamin D recommendations based on the avoidance of gestational hypertensive disorders alone. However, this review supports the findings from two recent meta-analyses of observational studies that have shown a significant association between vitamin D deficiency and PE risk [26,27]. Notwithstanding the controversy regarding appropriate $25(\mathrm{OH}) \mathrm{D}$ cut-off points for vitamin $\mathrm{D}$ deficiency, both meta-analyses observed a significant correlation when deficiency was defined as $25(\mathrm{OH}) \mathrm{D}$ concentrations $<50 \mathrm{nmol} / \mathrm{L}$ [26,27]. Of note is that, in the subgroup analysis reported by Tabesh [27], the inverse relationship was significant for studies conducted in the United States only, suggesting the vitamin D-PE interaction may be region-specific and reiterates the need for consideration of variation in latitude and ethnicity in vitamin D association studies.

We identified several challenges in our interpretations. In terms of study design, vitamin D status is often only evaluated at a single time point throughout gestation, frequently in the late second or third trimester, when it may be too late to intervene. It is likely that $25(\mathrm{OH}) \mathrm{D}$ measurements throughout each trimester would give a clearer understanding of any potential cause and effect relationship [48] and the most effective strategy for intervention. Furthermore, if 25(OH)D is measured following PE diagnosis, reverse causality cannot be discounted, and the results, therefore, offer limited clinical utility. In addition to analytical differences, the lack of consensus regarding a 25(OH)D cut-off to define vitamin D sufficiency hampers international comparisons of deficiency prevalence and subsequent risk of adverse health outcomes, including PE and gestational hypertension. 25(OH)D data must be reported across all studies using a range of thresholds to facilitate cross-comparison between populations. Based on a $25(\mathrm{OH}) \mathrm{D}-\mathrm{PE}$ risk curve, a concentration of $<50 \mathrm{nmol} / \mathrm{L}$ has been suggested [36]. However, specific threshold values at which the risk of PIH is increased may vary based on certain physiological attributes, including BMI, race, and gestational age, all of which may interfere with vitamin D status. It is, therefore, plausible that a range, rather than a specific cut-off point, for 25(OH)D exists in which women are less likely to develop PIH.

To date, a lack of evidence from long-term, high-dose vitamin D supplementation trials undermines our confidence around potential adverse effects associated with the prolonged use of high-dose vitamin D supplements [71]. However, obtaining trial data to specifically assess the risk of adverse outcomes at high concentrations is ethically challenging and likely requires an individual participant level (IPD)-analysis approach of past intervention trials with safety outcomes. In light of the increased risk of hypertension among women in Project Viva [61,62], and the uncertainty surrounding the concentration at which risk of hypercalcaemia increases, caution should be urged with regards to dosing, especially in pregnancy.

Our analysis of the literature clearly identifies the need to conduct a large dose-response RCT, considering race, season and background diet, including calcium intake, to determine whether improved vitamin D status will help protect against PIH. Implementation of such a trial must consider the dose-response relationship of serum 25(OH)D to total vitamin D intake [18]. In the absence of pregnancy-specific values, regulatory agencies currently recommend a minimum vitamin $\mathrm{D}$ intake of $400 \mathrm{IU} /$ day $[11,72]$ sufficient to protect against maternal deficiency at a threshold of 25-30 nmol/L, but this will not protect against neonatal deficiency at the same threshold [73]. It is now likely that ethical review boards may no longer approve a true placebo group in pregnancy trials with vitamin $D$, meaning future intervention studies might be required to screen at baseline for deficiency [74] or supplement a 'low' intake group, resulting in a minimum $25(\mathrm{OH}) \mathrm{D}$ concentration range of $\geq 30 \mathrm{nmol} / \mathrm{L}$. For outcomes such as PIH, and PE in particular, where narrow ranges of $25(\mathrm{OH}) \mathrm{D}$ concentrations could be pivotal to determining a reduction in incidence rates, the absence of a true placebo group may pose further experimental challenges [18]. 


\section{Conclusions}

This review critically evaluates the current evidence for an association between vitamin D status and/or intake and risk of hypertensive disorders in pregnancy. The inclusion of both observational and interventional studies helped to avoid potential oversight in the published research as the limited quantity of data produced by interventional studies alone may limit our understanding of the state of the art with regard to vitamin D and PIH. While most studies report serum 25(OH)D concentrations, we also reported studies of maternal vitamin D intakes to ensure a comprehensive analysis. Another strength of this review is that it reports outcomes relating to all terms of PIH and is not limited to $\mathrm{PE}$. Systematic reviews to date have been unable to draw firm conclusions regarding the potential of vitamin $\mathrm{D}$ to protect against gestational hypertensive disorders. Evidence from RCTs are limited to PE prevention and the current evidence base is weak and subject to a high risk of bias. Data from trials using combined vitamin $\mathrm{D}$ and calcium supplementation support a protective effect against PE among the supplemented groups. Observational cohort studies show a positive association between vitamin D deficiency and increased risk of PE, but results are hampered by suboptimal clinical phenotyping, incomplete subject characterisation and large heterogeneity between studies. Estimates of vitamin D intakes in observational studies are usually absent and, in those that report exposure levels, the overwhelming effect of micronutrient supplementation on vitamin D intakes opens the possibility of confounding by other nutrients. In light of evidence for a mechanistic role for vitamin $\mathrm{D}$ in the metabolic adaptation of healthy pregnancy, it is biologically plausible that the dysregulated metabolite concentrations in unhealthy pregnancies (including PE) may, in part, result from a deficiency in vitamin D [15]. We, therefore, extend the view expressed by several investigators, who stress a need for an adequately-powered, well-conducted RCT to establish a causal effect between vitamin D deficiency and increased risk of PE.

Acknowledgments: This research was supported by funding to M.K. from the European Commission under its Seventh Framework Programme (FP7/2007-2013) under grant agreement 613977 for the ODIN Integrated Project (Food-based solutions for optimal vitamin D nutrition and health throughout the life cycle; http://www.odinvitd.eu/). This review was conducted with the assistance of the academic module "Systematic Reviews for the Health Sciences" (PG7016) led by Prof John Browne, Department of Epidemiology and Public Health, University College Cork, Ireland.

Author Contributions: K.M.O.C. devised the search strategy and performed data extraction; and both K.M.O.C. and M.K. wrote the paper, and revised and edited the manuscript. M.K. was responsible for the final content.

Conflicts of Interest: The authors declare no conflict of interest. The founding sponsors had no role in the collection or interpretation of the data, in the writing of the manuscript or in the decision to publish this review.

\section{References}

1. World Health Organisation. Who guidelines approved by the guidelines review committee. In Who Recommendations for Prevention and Treatment of Pre-Eclampsia and Eclampsia; WHO: Geneva, Switzerland, 2011.

2. American College of Obstetricians and Gynecologists. Hypertension in pregnancy. Report of the American College of Obstetricians and Gynecologists' Task Force on Hypertension in Pregnancy. Obstet. Gynecol. 2013, 122, 1122-1131.

3. Tranquilli, A.L.; Dekker, G.; Magee, L.; Roberts, J.; Sibai, B.M.; Steyn, W.; Zeeman, G.G.; Brown, M.A. The classification, diagnosis and management of the hypertensive disorders of pregnancy: A revised statement from the isshp. Pregnancy Hypertens. 2014, 4, 97-104. [CrossRef] [PubMed]

4. Hutcheon, J.A.; Lisonkova, S.; Joseph, K.S. Epidemiology of pre-eclampsia and the other hypertensive disorders of pregnancy. Best Pract. Res. Clin. Obstet. Gynaecol. 2011, 25, 391-403. [CrossRef] [PubMed]

5. Zakiyah, N.; Postma, M.J.; Baker, P.N.; van Asselt, A.D. On Behalf of the IMPROvED Consortium. Pre-eclampsia diagnosis and treatment options: A review of published economic assessments. Pharmacoeconomics 2015, 33, 1069-1082. [CrossRef] [PubMed]

6. Duley, L. Pre-eclampsia and the hypertensive disorders of pregnancy. Br. Med. Bull. 2003, 67, 161-176. [CrossRef] [PubMed] 
7. Meads, C.A.; Cnossen, J.S.; Meher, S.; Juarez-Garcia, A.; Ter Riet, G.; Duley, L.; Roberts, T.E.; Mol, B.W.; van der Post, J.A.; Leeflang, M.M.; et al. Methods of prediction and prevention of pre-eclampsia: Systematic reviews of accuracy and effectiveness literature with economic modelling. Health Technol. Assess. 2008, 12, 1-270. [CrossRef]

8. Snydal, S. Major changes in diagnosis and management of preeclampsia. J. Midwifery Womens Health 2014, 59, 596-605. [CrossRef] [PubMed]

9. James, J.L.; Whitley, G.S.; Cartwright, J.E. Pre-eclampsia: Fitting together the placental, immune and cardiovascular pieces. J. Pathol. 2010, 221, 363-378. [CrossRef] [PubMed]

10. Zehnder, D.; Evans, K.N.; Kilby, M.D.; Bulmer, J.N.; Innes, B.A.; Stewart, P.M.; Hewison, M. The ontogeny of 25-hydroxyvitamin $\mathrm{D}$ (3) 1alpha-hydroxylase expression in human placenta and decidua. Am. J. Pathol. 2002, 161, 105-114. [CrossRef]

11. Institute of Medicine. Dietary Reference Intakes for Calcium and Vitamin D; National Academies Press: Washington, DC, USA, 2011.

12. Zhang, J.Y.; Lucey, A.J.; Horgan, R.; Kenny, L.C.; Kiely, M. Impact of pregnancy on vitamin D status: A longitudinal study. Br. J. Nutr. 2014, 112, 1081-1087. [CrossRef] [PubMed]

13. Papapetrou, P.D. The interrelationship of serum 1,25-dihydroxyvitamin D, 25-hydroxyvitamin D and 24,25-dihydroxyvitamin D in pregnancy at term: A meta-analysis. Hormones 2010, 9, 136-144. [CrossRef] [PubMed]

14. Saffery, R.; Ellis, J.; Morley, R. A convergent model for placental dysfunction encompassing combined sub-optimal one-carbon donor and vitamin D bioavailability. Med. Hypotheses 2009, 73, 1023-1028. [CrossRef] [PubMed]

15. Tamblyn, J.A.; Susarla, R.; Jenkinson, C.; Jeffery, L.E.; Ohizua, O.; Chun, R.F.; Chan, S.Y.; Kilby, M.D.; Hewison, M. Dysregulation of maternal and placental vitamin D metabolism in preeclampsia. Placenta 2017, 50, 70-77. [CrossRef] [PubMed]

16. Tamblyn, J.A.; Hewison, M.; Wagner, C.L.; Bulmer, J.N.; Kilby, M.D. Immunological role of vitamin D at the maternal-fetal interface. J. Endocrinol. 2015, 224, R107-R121. [CrossRef] [PubMed]

17. Saraf, R.; Morton, S.M.; Camargo, C.A., Jr.; Grant, C.C. Global summary of maternal and newborn vitamin D status-A systematic review. Matern. Child Nutr. 2016, 12, 647-668. [CrossRef] [PubMed]

18. Kiely, M.; Hemmingway, A.; O'Callaghan, K.M. Vitamin D in pregnancy: Current perspectives and future directions. Ther. Adv. Musculoskelet. Dis. 2017, 9, 145-154. [CrossRef] [PubMed]

19. Shin, J.S.; Choi, M.Y.; Longtine, M.S.; Nelson, D.M. Vitamin D effects on pregnancy and the placenta. Placenta 2010, 31, 1027-1034. [CrossRef] [PubMed]

20. Díaz, L.; Arranz, C.; Avila, E.; Halhali, A.; Vilchis, F.; Larrea, F. Expression and activity of 25-hydroxyvitamin D-1 alpha-hydroxylase are restricted in cultures of human syncytiotrophoblast cells from preeclamptic pregnancies. J. Clin. Endocrinol. Metab. 2002, 87, 3876-3882. [PubMed]

21. Fischer, D.; Schroer, A.; Lüdders, D.; Cordes, T.; Bücker, B.; Reichrath, J.; Friedrich, M. Metabolism of vitamin D3 in the placental tissue of normal and preeclampsia complicated pregnancies and premature births. Clin. Exp. Obstet. Gynecol. 2007, 34, 80-84. [PubMed]

22. Ma, R.; Gu, Y.; Zhao, S.; Sun, J.; Groome, L.J.; Wang, Y. Expressions of vitamin D metabolic components VDBP, CYP2R1, CYP27B1, CYP24A1, and VDR in placentas from normal and preeclamptic pregnancies. Am. J. Physiol. Endocrinol. Metab. 2012, 303, E928-E935. [CrossRef] [PubMed]

23. Díaz, L.; Noyola-Martínez, N.; Barrera, D.; Hernández, G.; Avila, E.; Halhali, A.; Larrea, F. Calcitriol inhibits TNF-alpha-induced inflammatory cytokines in human trophoblasts. J. Reprod. Immunol. 2009, 81, 17-24. [CrossRef] [PubMed]

24. Lewis, S.; Lucas, R.M.; Halliday, J.; Ponsonby, A.L. Vitamin D deficiency and pregnancy: From preconception to birth. Mol. Nutr. Food Res. 2010, 54, 1092-1102. [CrossRef] [PubMed]

25. Lapillonne, A. Vitamin D deficiency during pregnancy may impair maternal and fetal outcomes. Med. Hypotheses 2010, 74, 71-75. [CrossRef] [PubMed]

26. Aghajafari, F.; Nagulesapillai, T.; Ronksley, P.E.; Tough, S.C.; O’Beirne, M.; Rabi, D.M. Association between maternal serum 25-hydroxyvitamin $\mathrm{D}$ level and pregnancy and neonatal outcomes: Systematic review and meta-analysis of observational studies. BMJ 2013, 346, f1169. [CrossRef] [PubMed] 
27. Tabesh, M.; Salehi-Abargouei, A.; Tabesh, M.; Esmaillzadeh, A. Maternal vitamin D status and risk of pre-eclampsia: A systematic review and meta-analysis. J. Clin. Endocrinol. Metab. 2013, 98, 3165-3173. [CrossRef] [PubMed]

28. De-Regil, L.M.; Palacios, C.; Lombardo, L.K.; Peña-Rosas, J.P. Vitamin D Supplementation for Women during Pregnancy. Cochrane Database Syst. Rev. 2016, 14, CD008873. [CrossRef]

29. Wei, S.Q.; Qi, H.P.; Luo, Z.C.; Fraser, W.D. Maternal vitamin D status and adverse pregnancy outcomes: A systematic review and meta-analysis. J. Matern. Fetal Neonatal Med. 2013, 26, 889-899. [CrossRef] [PubMed]

30. Hyppönen, E.; Cavadino, A.; Williams, D.; Fraser, A.; Vereczkey, A.; Fraser, W.D.; Bánhidy, F.; Lawlor, D.; Czeizel, A.E. Vitamin D and pre-eclampsia: Original data, systematic review and meta-analysis. Ann. Nutr. Metab. 2013, 63, 331-340. [CrossRef] [PubMed]

31. Swiglo, B.A.; Murad, M.H.; Schünemann, H.J.; Kunz, R.; Vigersky, R.A.; Guyatt, G.H.; Montori, V.M. A case for clarity, consistency, and helpfulness: State-of-the-art clinical practice guidelines in endocrinology using the grading of recommendations, assessment, development, and evaluation system. J. Clin. Endocrinol. Metab. 2008, 93, 666-673. [CrossRef] [PubMed]

32. Asemi, Z.; Samimi, M.; Tabassi, Z.; Shakeri, H.; Esmaillzadeh, A. Vitamin D supplementation affects serum high-sensitivity $\mathrm{C}$-reactive protein, insulin resistance, and biomarkers of oxidative stress in pregnant women. J. Nutr. 2013, 143, 1432-1438. [CrossRef] [PubMed]

33. Hossain, N.; Kanani, F.H.; Ramzan, S.; Kausar, R.; Ayaz, S.; Khanani, R.; Pal, L. Obstetric and neonatal outcomes of maternal vitamin D supplementation: Results of an open-label, randomized controlled trial of antenatal vitamin D supplementation in Pakistani women. J. Clin. Endocrinol. Metab. 2014, 99, 2448-2455. [CrossRef] [PubMed]

34. Asemi, Z.; Samimi, M.; Siavashani, M.A.; Mazloomi, M.; Tabassi, Z.; Karamali, M.; Jamilian, M.; Esmaillzadeh, A. Calcium-vitamin D co-supplementation affects metabolic profiles, but not pregnancy outcomes, in healthy pregnant women. Int. J. Prev. Med. 2016, 7, 49. [PubMed]

35. Bärebring, L.; Bullarbo, M.; Glantz, A.; Leu Agelii, M.; Jagner, A.; Ellis, J.; Hulthén, L.; Schoenmakers, I.; Augustin, H. Preeclampsia and blood pressure trajectory during pregnancy in relation to vitamin D status. PLoS ONE 2016, 11, e0152198. [CrossRef] [PubMed]

36. Wei, S.Q.; Audibert, F.; Hidiroglou, N.; Sarafin, K.; Julien, P.; Wu, Y.; Luo, Z.C.; Fraser, W.D. Longitudinal vitamin D status in pregnancy and the risk of pre-eclampsia. BJOG 2012, 119, 832-839. [CrossRef] [PubMed]

37. Shand, A.W.; Nassar, N.; Von Dadelszen, P.; Innis, S.M.; Green, T.J. Maternal vitamin D status in pregnancy and adverse pregnancy outcomes in a group at high risk for pre-eclampsia. BJOG 2010, 117, 1593-1598. [CrossRef] [PubMed]

38. Hossain, N.; Khanani, R.; Hussain-Kanani, F.; Shah, T.; Arif, S.; Pal, L. High prevalence of vitamin D deficiency in Pakistani mothers and their newborns. Int. J. Gynaecol. Obstet. 2011, 112, 229-233. [CrossRef] [PubMed]

39. Kiely, M.E.; Zhang, J.Y.; Kinsella, M.; Khashan, A.S.; Kenny, L.C. Vitamin D status is associated with uteroplacental dysfunction indicated by pre-eclampsia and small-for-gestational-age birth in a large prospective pregnancy cohort in ireland with low vitamin D status. Am. J. Clin. Nutr. 2016, 104, 354. [CrossRef] [PubMed]

40. Achkar, M.; Dodds, L.; Giguère, Y.; Forest, J.C.; Armson, B.A.; Woolcott, C.; Agellon, S.; Spencer, A.; Weiler, H.A. Vitamin D status in early pregnancy and risk of preeclampsia. Am. J. Obstet. Gynecol. 2015, 212. [CrossRef] [PubMed]

41. Scholl, T.O.; Chen, X.; Stein, T.P. Vitamin D, secondary hyperparathyroidism, and preeclampsia. Am. J. Clin. Nutr. 2013, 98, 787-793. [CrossRef] [PubMed]

42. Wei, S.Q.; Audibert, F.; Luo, Z.C.; Nuyt, A.M.; Masse, B.; Julien, P.; Fraser, W.D. Maternal plasma 25-hydroxyvitamin D levels, angiogenic factors, and preeclampsia. Am. J. Obstet. Gynecol. 2013, 208. [CrossRef] [PubMed]

43. Bomba-Opon, D.A.; Brawura-Biskupski-Samaha, R.; Kozlowski, S.; Kosinski, P.; Bartoszewicz, Z.; Bednarczuk, T.; Wielgos, M. First trimester maternal serum vitamin D and markers of preeclampsia. J. Mater. Fetal Neonatal Med. 2014, 27, 1078-1079. [CrossRef] [PubMed]

44. Álvarez-Fernandez, I.; Prieto, B.; Rodríguez, V.; Ruano, Y.; Escudero, A.I.; Álvarez, F.V. Role of vitamin D and sFlt-1/PlGF ratio in the development of early- and late-onset preeclampsia. Clin. Chem. Lab. Med. 2015, 53, 1033-1040. [CrossRef] [PubMed] 
45. Woodham, P.C.; Brittain, J.E.; Baker, A.M.; Long, D.L.; Haeri, S.; Camargo, C.A., Jr.; Boggess, K.A.; Stuebe, A.M. Midgestation maternal serum 25-hydroxyvitamin D level and soluble fms-like tyrosine kinase 1/placental growth factor ratio as predictors of severe preeclampsia. Hypertension 2011, 58, 1120-1125. [CrossRef] [PubMed]

46. Zabul, P.; Wozniak, M.; Slominski, A.T.; Preis, K.; Gorska, M.; Korozan, M.; Wieruszewski, J.; Zmijewski, M.A.; Zabul, E.; Tuckey, R.; et al. A proposed molecular mechanism of high-dose vitamin D3 supplementation in prevention and treatment of preeclampsia. Int. J. Mol. Sci. 2015, 16, 13043-13064. [CrossRef] [PubMed]

47. Xu, L.; Lee, M.; Jeyabalan, A.; Roberts, J.M. The relationship of hypovitaminosis D and IL-6 in preeclampsia. Am. J. Obstet. Gynecol. 2014, 210, 141-147. [CrossRef] [PubMed]

48. Wetta, L.A.; Biggio, J.R.; Cliver, S.; Abramovici, A.; Barnes, S.; Tita, A.T. Is midtrimester vitamin D status associated with spontaneous preterm birth and preeclampsia? Am. J. Perinatol. 2014, 31, 541-546. [PubMed]

49. Gidlöf, S.; Silva, A.T.; Gustafsson, S.; Lindqvist, P.G. Vitamin D and the risk of preeclampsia-A nested case-control study. Acta Obstet. Gynecol. Scand. 2015, 94, 904-908. [CrossRef] [PubMed]

50. Schneuer, F.J.; Roberts, C.L.; Guilbert, C.; Simpson, J.M.; Algert, C.S.; Khambalia, A.Z.; Tasevski, V.; Ashton, A.W.; Morris, J.M.; Nassar, N. Effects of maternal serum 25-hydroxyvitamin D concentrations in the first trimester on subsequent pregnancy outcomes in an Australian population. Am. J. Clin. Nutr. 2014, 99, 287-295. [CrossRef] [PubMed]

51. Lechtermann, C.; Hauffa, B.P.; Herrmann, R.; Schündeln, M.M.; Gellhaus, A.; Schmidt, M.; Grasemann, C. Maternal vitamin D status in preeclampsia: Seasonal changes are not influenced by placental gene expression of vitamin D metabolizing enzymes. PLoS ONE 2014, 9, e105558. [CrossRef] [PubMed]

52. Anderson, C.M.; Ralph, J.L.; Johnson, L.; Scheett, A.; Wright, M.L.; Taylor, J.Y.; Ohm, J.E.; Uthus, E. First trimester vitamin $\mathrm{D}$ status and placental epigenomics in preeclampsia among Northern Plains primiparas. Life Sci. 2015, 129, 10-15. [CrossRef] [PubMed]

53. Robinson, C.J.; Wagner, C.L.; Hollis, B.W.; Baatz, J.E.; Johnson, D.D. Association of maternal vitamin D and placenta growth factor with the diagnosis of early onset severe preeclampsia. Am. J. Perinatol. 2013, 30, 167-172. [PubMed]

54. Pena, H.R.; de Lima, M.C.; Brandt, K.G.; de Antunes, M.M.; da Silva, G.A. Influence of preeclampsia and gestational obesity in maternal and newborn levels of vitamin D. BMC Pregnancy Childbirth 2015, 15, 112. [CrossRef] [PubMed]

55. Abedi, P.; Mohaghegh, Z.; Afshary, P.; Latifi, M. The relationship of serum vitamin D with pre-eclampsia in the Iranian women. Matern. Child Nutr. 2014, 10, 206-212. [CrossRef] [PubMed]

56. Mohaghegh, Z.; Abedi, P.; Dilgouni, T.; Namvar, F.; Ruzafza, S. The relation of preeclampsia and serum level of 25-hydroxyvitamin D in mothers and their neonates: A case control study in Iran. Horm. Metab. Res. 2015, 47, 284-288. [CrossRef] [PubMed]

57. Ullah, M.I.; Koch, C.A.; Tamanna, S.; Rouf, S.; Shamsuddin, L. Vitamin D deficiency and the risk of preeclampsia and eclampsia in Bangladesh. Horm. Metab. Res. 2013, 45, 682-687. [CrossRef] [PubMed]

58. Bodnar, L.M.; Simhan, H.N.; Catov, J.M.; Roberts, J.M.; Platt, R.W.; Diesel, J.C.; Klebanoff, M.A. Maternal vitamin D status and the risk of mild and severe preeclampsia. Epidemiology 2014, 25, 207-214. [CrossRef] [PubMed]

59. Singla, R.; Gurung, P.; Aggarwal, N.; Dutta, U.; Kochhar, R. Relationship between preeclampsia and vitamin D deficiency: A case control study. Arch. Gynecol. Obstet. 2015, 291, 1247-1251. [CrossRef] [PubMed]

60. Haugen, M.; Brantsaeter, A.L.; Trogstad, L.; Alexander, J.; Roth, C.; Magnus, P.; Meltzer, H.M. Vitamin D supplementation and reduced risk of preeclampsia in nulliparous women. Epidemiology 2009, 20, 720-726. [CrossRef] [PubMed]

61. Burris, H.H.; Rifas-Shiman, S.L.; Huh, S.Y.; Kleinman, K.; Litonjua, A.A.; Oken, E.; Rich-Edwards, J.W.; Camargo, C.A., Jr.; Gillman, M.W. Vitamin D status and hypertensive disorders in pregnancy. Ann. Epidemiol. 2014, 24, 399-403. [CrossRef] [PubMed]

62. Oken, E.; Ning, Y.; Rifas-Shiman, S.L.; Rich-Edwards, J.W.; Olsen, S.F.; Gillman, M.W. Diet during pregnancy and risk of preeclampsia or gestational hypertension. Ann. Epidemiol. 2007, 17, 663-668. [CrossRef] [PubMed]

63. Al-Shaikh, G.K.; Ibrahim, G.H.; Fayed, A.A.; Al-Mandeel, H. Impact of vitamin D deficiency on maternal and birth outcomes in the Saudi population: A cross-sectional study. BMC Pregnancy Childbirth 2016, 16, 119. [CrossRef] [PubMed] 
64. Ringrose, J.S.; PausJenssen, A.M.; Wilson, M.; Blanco, L.; Ward, H.; Wilson, T.W. Vitamin D and hypertension in pregnancy. Clin. Investig. Med. 2011, 34, E147-E154. [CrossRef]

65. Kazemian, E.; Dorosty-Motlagh, A.R.; Sotoudeh, G.; Eshraghian, M.R.; Ansary, S.; Omidian, M. Nutritional status of women with gestational hypertension compared with normal pregnant women. Hypertens. Pregnancy 2013, 32, 146-156. [CrossRef] [PubMed]

66. Arain, N.; Mirza, W.A.; Aslam, M. Review-vitamin D and the prevention of preeclampsia: A systematic review. Pak. J. Pharm. Sci. 2015, 28, 1015-1021. [PubMed]

67. Harvey, N.C.; Holroyd, C.; Ntani, G.; Javaid, K.; Cooper, P.; Moon, R.; Cole, Z.; Tinati, T.; Godfrey, K.; Dennison, E.; et al. Vitamin D supplementation in pregnancy: A systematic review. Health Technol. Assess. 2014, 18, 1-190. [CrossRef] [PubMed]

68. Christesen, H.T.; Falkenberg, T.; Lamont, R.F.; Jorgensen, J.S. The impact of vitamin D on pregnancy: A systematic review. Acta Obstet. Gynecol. Scand. 2012, 91, 1357-1367. [CrossRef] [PubMed]

69. Thorne-Lyman, A.; Fawzi, W.W. Vitamin D during pregnancy and maternal, neonatal and infant health outcomes: A systematic review and meta-analysis. Paediatr. Perinat. Epidemiol. 2012, 26, 75-90. [CrossRef] [PubMed]

70. Nassar, N.; Halligan, G.H.; Roberts, C.L.; Morris, J.M.; Ashton, A.W. Systematic review of first-trimester vitamin D normative levels and outcomes of pregnancy. Am. J. Obstet. Gynecol. 2011, 205, 208.e1-208.e7. [CrossRef] [PubMed]

71. Jones, G. Pharmacokinetics of vitamin D toxicity. Am. J. Clin. Nutr. 2008, 88, 582S-586S. [CrossRef] [PubMed]

72. Scientific Advisory Committee on Nutrition. Report on Vitamin D and Health. Available online: https: //www.gov.uk/government/publications/sacn-vitamin-d-and-health-report (accessed on 24 May 2017).

73. March, K.M.; Chen, N.N.; Karakochuk, C.D.; Shand, A.W.; Innis, S.M.; von Dadelszen, P.; Barr, S.I.; Lyon, M.R.; Whiting, S.J.; Weiler, H.A.; et al. Maternal vitamin D(3) supplementation at $50 \mathrm{mug} / \mathrm{d}$ protects against low serum 25-hydroxyvitamin D in infants at $8 \mathrm{wk}$ of age: A randomized controlled trial of 3 doses of vitamin D beginning in gestation and continued in lactation. Am. J. Clin. Nutr. 2015, 102, 402-410. [CrossRef] [PubMed]

74. Cooper, C.; Harvey, N.C.; Bishop, N.J.; Kennedy, S.; Papageorghiou, A.T.; Schoenmakers, I.; Fraser, R.; Gandhi, S.V.; Carr, A.; D’Angelo, S.; et al. Maternal gestational vitamin D supplementation and offspring bone health (MAVIDOS): A multicentre, double-blind, randomised placebo-controlled trial. Lancet Diabetes Endocrinol. 2016, 4, 393-402. [CrossRef] 